\title{
Re-establishment of an endangered subspecies: the Norfolk Island Boobook Owl Ninox novaeseelandiae undulata
}

\author{
PENNY D. OLSEN
}

\section{Summary}

The Norfolk Island Boobook Ninox novaeseelandiae undulata is confined to the small, isolated Norfolk Island group, an Australian territory. On morphological and biogeographical grounds, it is here classified as a large, distinctive subspecies of the New Zealand Morepork N. novaeseelandiae. In 1986 only one specimen, a female, survived. A shortage of large trees with suitable nesting holes appeared to be the immediate problem. The Australian Nature Conservation Agency, islanders and New Zealand wildlife authorities have cooperated in an attempt to re-establish an owl population in situ. Nest-boxes were erected in trees in the area frequented by the female and were used readily as roosts. In September 1987, two male New Zealand Moreporks were introduced. The female paired with one male and produced four hybrid $F_{1}$ offspring (in 1989 and 1990). Two of these paired in mid-1991 and have since produced five $F_{2}$ offspring (two in 1993 and three in 1994). The original female remains paired but now appears to be reproductively senile. At present there seems to be a shortage of mature males, since two female offspring are paired and both lay eggs and attempt to incubate them in the same nest; and a lone female has established a territory. In early 1995 all eleven owls appeared to be alive in the wild. The effort is low-cost, requires relatively little manpower, is carried out with minimal disturbance to the owls, and goes hand in hand with other conservation programmes.

\section{Introduction and history}

Norfolk Island $\left(29^{\circ} 05^{\prime} \mathrm{S} 167^{\circ} 59^{\prime} \mathrm{E}\right)$ is a small, isolated Australian territory, 3,450 ha in area and situated $1,367 \mathrm{~km}$ east of mainland Australia. Two other small islands, Nepean and larger Philip Island (c. $2 \mathrm{~km}^{2}$ ), complete the Norfolk Island Group, $772 \mathrm{~km}$ north-west of New Zealand and $675 \mathrm{~km}$ from New Caledonia, its nearest neighbour.

When Cook discovered Norfolk Island in 1774 it was covered in rainforest. Clearing began when the island was first used as a penal settlement, between 1788 and 1814, and continued during the second most infamous historical period, 1825-1856. By the early 1900s, three-quarters of the forest had been cleared and the remainder had deteriorated from logging of prime trees, infestation by weeds and degeneration from exposure (Lane-Poole 1926, Smithers and Disney 1969, Schodde et al. 1983). In 1986 the Norfolk Island National Park (NINP) was proclaimed; it encompasses $12 \%$ of the island, 
including the two mountains, Mt Pitt and Mt Bates (the highest reaching $318 \mathrm{~m}$ ), and the only remaining intact fragments of the original forest.

Today approximately 1,800 people inhabit the island group. Many are descendants of the Bounty mutineers relocated from Pitcairn Island. Habitat destruction, and deliberate introductions and self-introductions of exotic plants and animals, have resulted in several extinctions and depleted the populations of many of the remaining indigenous taxa. Since settlement, six of the group's fourteen endemic landbirds have become extinct, and a seventh has not been seen for several years despite considerable efforts to find it. An eighth species, the Red-fronted Parakeet or Norfolk Island Green Parrot Cyanoramphus novaezelandiae cooki, numbers about 30 individuals and requires extensive management to protect it from rats, cats and introduced bird species. Of the ninth species, the Norfolk Island Boobook Ninox novaeseelandiae undulata, only one individual remains (Olsen 1989, Olsen et al. 1989).

The Norfolk Island Boobook is considered to be a distinctive subspecies of the New Zealand Morepork Ninox novaeseelandiae. It is one of 26 of the world's owl taxa listed as endangered, but currently the only such owl taxon in Australia (Clarke et al. 1978, King 1978-1979, Garnett 1992). First described by Latham (1801), the owl almost certainly would have occurred throughout the island, but since 1909 it is said to have been confined largely to gullies surrounding $\mathrm{Mt}$ Pitt (Bassett-Hull 1910, Turner et al. 1968, Smithers and Disney 1969), although according to the islanders occasionally it is seen in more open country. From this apparently already depleted population, Bell (1912-1913), with a permit to remove six owls, took 30 specimens for a Sydney collector. Most biologists subsequently visiting the island heard few if any owls (Wakelin 1968, De Ravin 1975, King 1978-1979, Moore 1981). As early as the 1960s a lack of holes for nest sites, owing to logging of mature trees, was identified as a major threat to the owl population (Turner et al. 1968, King 1978-1979). During a survey of the island's birds in 1978 perhaps three individual owls were heard (Schodde et al. 1983, Rooke 1986). An intensive search in 1985 was unsuccessful, but because locals still heard an owl it was concluded that only one existed with certainty (Rooke 1986).

A group of concerned ornithologists visited the island in 1986 and, assisted by on-island Australian Nature Conservation Agency (ANCA) staff and locals, were able to find only one owl, thought to be a female, which was trapped for measurement and marking, and released (Olsen et al. 1989). A severe shortage of suitable nest sites was considered the most obvious problem, but predation and/or competition from introduced species was also suspected.

Recommendations were made to re-establish an owl population on Norfolk Island based on the diagnosis of cause of decline and treatment (declining-population paradigm) and managed wild breeding (small-population paradigm). Caughley (1994) believed that "cautious" mixing of these two themes of conservation biology, the declining-population paradigm (the cause of smallness and its cure) and the small-population paradigm (the effect of smallness on persistence of the population), might lead to a reduction in extinctions; yet he could find only one example of such a mixing of conservation perspectives, that of another Australian species, the Lord Howe Woodhen Tricholimnas sylvestris. 
Doubts over the number of surviving owls led to a follow-up survey in 1987 during which the original female was seen on several occasions, but no additional owls were located (Olsen 1987). Recommendations for a wild-based re-establishment programme were made, nest-boxes were erected, and in September 1987 two males of the ostensibly closest extant subspecies, the New Zealand Morepork, were released (Olsen et al. 1989).

\section{The case for conservation action}

There are many reasons to conserve particular taxa, and a variety of considerations to be made when allocating conservation priorities: right to existence; ethical and compassionate considerations; aesthetic appeal; likelihood of success; cost; maintaining environmental balance and preserving genetic diversity; political/community support and other scientific and social concerns (Kennedy 1990, Garnett 1992). Most of these can be applied to the Norfolk Island Boobook with affirmative results, cost (for example) being low in part as a result of many other ongoing conservation initiatives on the island.

Garnett (1992) argues convincingly for the use of the subspecies as the "best compromise unit" for conservation currently available in Australia between species on the one side and populations on the other. The Lord Howe Island Boobook N. n. albaria, another distinctive subspecies, was extinct by 1950 . Without immediate management intervention the Norfolk Island Boobook would also have disappeared totally. If a viable population of hybrids can be established then some of the genetic character of the original population will be preserved. Moreover, the plight of such critically threatened taxa often provides the impetus for management intervention that benefits other species under threat. Indeed, being the top predator on the island the owl could be argued to have importance as a keystone species (as defined in Dietz et al. 1994). The Norfolk Islanders have a strong, independent identity which encompasses a sense of ownership and a wish to preserve the integrity of the island; in general, they greatly favour an attempt to save the owl.

\section{Reasons for the decline}

As with many island extinctions (King 1985), the decline of the Norfolk Island Owl population was probably caused by a combination of sometimes unrelated environmental, demographic and genetic forces acting on a naturally small population. The cause of endangerment may well have differed from the cause of near extinction. Because so little is known about the pattern of loss of the owl population it is difficult to tie the decline, even circumstantially, to particular events.

Human activities are often disastrous in such small, isolated ecosystems as Norfolk Island: of 18 common factors contributing to extinction of local populations compiled by Soulé (1983), between 13 and 15 appear to apply to the owl. Habitat destruction is the major cause of endangerment of island birds (King 1985) and this seems likely to be so in the case of the Norfolk Island Boobook, at least in terms of nesting habitat (Table 1). Once the population was reduced below some critical threshold then other deleterious influences such as 
Table 1. Main hypotheses to be tested to account for recent decline in Norfolk Island Owl population

\begin{tabular}{|c|c|c|c|c|}
\hline \multicolumn{2}{|c|}{ Hypotheses for decline } & \multirow{2}{*}{$\begin{array}{l}\text { Mechanism } \\
\text { Clearing } \\
\text { Clearing/selective logging }\end{array}$} & \multirow{2}{*}{$\begin{array}{l}\text { Commenced }^{a} \\
1860 \\
1860-\text { recent }\end{array}$} & \multirow{2}{*}{$\begin{array}{l}\text { Other pop. }{ }^{b} \\
\text { New Zealand }\end{array}$} \\
\hline $\begin{array}{l}\text { Either: } \\
\text { Or: } \\
\text { Or: }\end{array}$ & $\begin{array}{l}\text { A Habitat loss (75\%) } \\
\text { B Nest site loss (most) } \\
\text { C Introduced predators }\end{array}$ & & & \\
\hline $\begin{array}{l}\text { Either: } \\
\text { Or: } \\
\text { Or: } \\
\text { Or: }\end{array}$ & $\begin{array}{l}\text { A Black Rat } \\
\text { B Polynesian Rat } \\
\text { C Cat } \\
\text { D Nest competitors }\end{array}$ & & $\begin{array}{l}1940 s ? \\
900-1000 \\
\text { late } 18005\end{array}$ & $\begin{array}{l}\text { New Zealand } \\
\text { New Zealand } \\
\text { New Zealand }\end{array}$ \\
\hline $\begin{array}{l}\text { Either: } \\
\text { Or: }\end{array}$ & $\begin{array}{l}\text { A Crimson Rosella } \\
\text { B Black Rat }\end{array}$ & & $\begin{array}{l}\text { by } 1840 \\
\text { 1940s? }\end{array}$ & $\begin{array}{l}\text { Australia }^{c} \\
\text { New Zealand }\end{array}$ \\
\hline
\end{tabular}

Presumably the owl population also declined when much of the island was cleared, in the $188 \mathrm{os}$. Because only one owl remains and virtually nothing is known of the biology of the population, circumstantial evidence is used for the tests. All of these factors are associated with the decline but are not necessarily causal. The tests are simplistic and assume that there are no interactions between factors, which is unlikely. As the owl population declined between 1913 (Bell's visit) and the 1960s (various reports), only loss of nest sites and the introduction of the black rat are linked temporally to the decline. However, the black rat does not appear to have had a significantly detrimental affect on New Zealand Morepork populations, thus the hypothesis of nest site loss is upheld.

${ }^{a}$ Commenced refers to the year of introduction in the case of animals, and to the year of removal for native habitat.

${ }^{b}$ Other pop. refers to other populations of $N$. novaeseelandiae subject to similar threats but which are not known to have declined.

'Similar species, at times considered conspecific (e.g. Mees 1964).

competition and predation may have become of greater importance. At very low numbers, sex ratio extinction is also likely: the last few individuals may all have been female, as they are larger and tend to live longer.

\section{Habitat loss}

Early descriptions suggest that the island was fairly uniformly forested: rainforest with emergent pines predominated, palms and ferns clothed gullies and wetter areas, and in most places the understorey was fairly open (King 1788-1790, cited in Hoare 1974). One-quarter of the forested island was cleared during the first convict settlement (1788-1814), and three-quarters had been cleared by the end of the second settlement (1856-1860). Selective logging of mature trees continues. Originally, Philip Island was scrub-covered, with a few scattered pines and forest in sheltered valleys, and Nepean Island was densely topped with pines (Schodde et al. 1983). Philip Island also had been all but totally denuded by the latter convict period, leaving a barren moonscape which has only recently begun to recover following successful removal of the introduced European rabbit Oryctolagus cuniculus. The forest-dwelling owl must have been affected by such a drastic reduction in prime habitat.

Remnant forest occurs mainly in NINP (about one-third of the park's $465 \mathrm{ha}$ ), and an additional 50 ha remains at scattered locations outside the park (Gilmore and Helman 1989). Woody weeds have invaded much of the forest, perhaps creating dense undergrowth that is not ideal for the owls. Nevertheless, boobooks in general are versatile little owls and would almost certainly have adapted to life in more open country, especially around pockets of trees in 
Table 2. (a) Prey remains cleared from the nest-boxes late in the nestling period and $(b)$ contents of a pellet ejected by the male New Zealand owl.

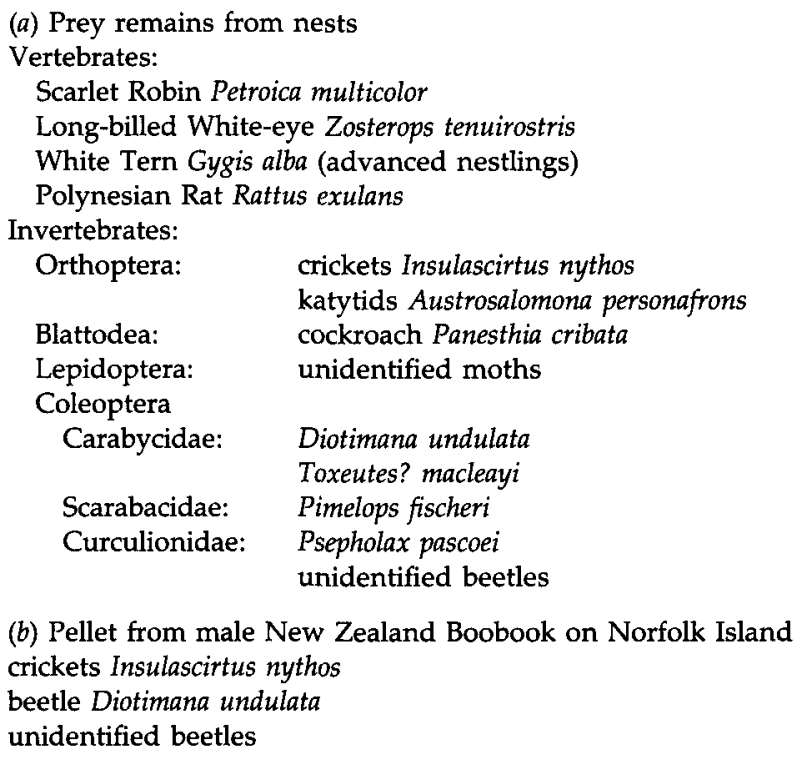

After Olsen 1990.

grazing country and forest edges and clearings. A reasonable population remained in 1912/1913, some 50 years after the worst of the clearing (Bell 19121913).

Food is sometimes considered to be a component of habitat. Bell (1912-1913) examined the stomachs of four owls and found only insect remains, and an apparent feeding roost with the remains of a White Tern Gygis alba was discovered by Moore (1981). Food remains in nest-boxes and pellets collected from under owl roosts, 1987-1994, consist mostly of insects, especially crickets (Table 2). However, vertebrates probably predominate in terms of prey biomass. Most of these species are abundant on the island.

\section{Destruction of nest sites}

Loss of suitable nest sites appears to be a far more damaging factor than general habitat reduction in the population decline. Given the expected versatility of the owl in terms of general habitat, it seems reasonable to assume that scarcity of nesting places was a primary factor in the decline of the population (Table 1). Selective logging of large mature trees from the remnant forest continues; these were almost certainly the trees with the hollows the owls used for roosting and, more importantly, nesting. At present, suitable tree cavities are extremely scarce and at a premium because of the number of species competing for them (see next section). If forced to use suboptimal sites, the owl may have suffered additional setbacks: for example, if a site flooded easily during rain, chilling eggs or young nestlings. 
Table 3. A comparison of the external dimensions of eight eggs apparently laid by two female hybrid chicks (banded blue and red-white/orange) in the same nest-box, in 1992 and 1994, with those of the New Zealand Morepork N. novaeseelandiae and Australian Boobook N. boobook.

\begin{tabular}{lcccc}
\hline Source & Norfolk Is $(n=1)$ & Hybrids $(n=4)$ & New Zealand $(n=3)$ & Australia $(n=231)$ \\
Length $(\mathrm{mm})$ & 3.76 & $3.95(3.86-4.04)$ & $3.76(3.72-3.80)$ & $4.16(3.78-4.63)$ \\
Breadth $(\mathrm{mm})$ & 3.10 & $3.46(3.36-3.59)$ & $3.17(2.98-3.27)$ & $3.55(3.17-4.10)$ \\
\hline
\end{tabular}

One infertile egg from the original Norfolk Island female was salvaged in 1993; given the size of the owl it appears to be rather small, perhaps due to reproductive senility, but no other eggs have ever been found for comparison. Mean and range shown, in $\mathrm{cm}$.

\section{Introduced competitors for nest sites}

The loss of nest sites by clearing and logging for timber has increased competition for places to reproduce or shelter. Although the native Green Parrot prefers nest sites with different characteristics to those used by owls, several introduced species use sites suitable for owls, including Crimson Rosellas Platycercus elegans, European Starlings Sturnus vulgaris (first recorded 1913: Hermes 1986), and honeybees from Italy. Of these, Crimson Rosellas show determined interest in nest-boxes established for the owl. The rosella was an early introduction, established by the 1840 (Hermes 1986, Anon. 1989, Hicks and Preece 1991) (Table 1). A potential secondary effect of the vertebrate competitors is the spread of disease and parasites. Bees may have caused the pure-bred female to desert her clutch in 1992 and could prove lethal to owls cornered in a nest or roost by a swarm.

Research on similar problems in New Zealand indicates that threatened native species were reduced first, then introductions thrived and became dominant, so that competition was not the primary cause of declines (Diamond and Veitch 1981). Regardless of cause and effect, however, the shortage of nest sites and intense competition for them is a severely limiting factor on Norfolk Island at present. Indeed, protection of nest sites from competitors and predators is a conservation necessity.

\section{Introduced predators}

Cats Felis cattus and rats have led to or been implicated in many extinctions on islands (Moors 1985, Veitch 1985). Of the three mammalian predators present on Norfolk Island, the black rat Rattus rattus has the potential to be a significant threat to the owl.

Both black and Polynesian rats $R$. exulans take birds up to their own weight. The black rat has caused extinctions and declines of several island birds (King 1985) and even the smaller Polynesian rat takes eggs up to $55 \mathrm{~mm}$ in length (well above the length of an owl egg: Table 3 ) and occasionally attacks birds larger than itself (Kepler 1967, Atkinson 1978). Hence both must be considered potential threats to the owls, particularly to their eggs and nestlings. The date of arrival of the black rat is uncertain, perhaps during the 1940s (Hicks and Preece 1991), not long before reports of the rarity of the owls began to appear. In contrast, the Polynesian rat appears in the fossil record, dated at 700-850 years BP (Schodde et al. 1983), and was probably introduced by Polynesian visitors, possibly AD 900-1000 (Atkinson 1985). Thus it has coexisted with the 
owl for at least that length of time. Moreover, the Polynesian rat nests on or near the ground, while the black rat nests high in trees using holes that may be important to the owls.

Cats were introduced last century (around 1838: Best 1966) and prefer ground-dwelling, nocturnal vertebrates weighing less than $600 \mathrm{~g}$ (Potter 1991, Anon. 1994). The owl is not ground-dwelling but occasionally visits the ground to capture prey (Australian Boobooks Ninox boobook occasionally roost on the ground in long vegetation). A cat could certainly catch an unwary or inexperienced owl. If the owl population was strong, cats might not be a major threat. However, when a species's population is very low, the loss of even one individual is drastic and any threat becomes major.

Two other predatory birds occur on the island. The migratory Swamp Harrier Circus approximans is an occasional visitor, but unlikely to prey on the owl. The Australian Kestrel Falco cenchroides is claimed to have self-colonized the island about 1969 (Schodde et al. 1983), but Bell (1912-1913) refers to quite common hawks with "bright brown eyes" and a "sparrowhawk", quite probably kestrels. The kestrel is quite common in cleared areas; it is a less a potential predator than a potential competitor for owl nest hollows, but it prefers to nest in more open situations.

\section{Pesticides}

A variety of rodenticides has been used, under uncontrolled conditions, to protect commercially cropped Kentia palm from rat attack, and it is possible that some owls suffered secondary poisoning. DDT and dieldrin have both been used for insect control; the first causes birds of prey to lay thin-shelled eggs that may not survive incubation, the second mortality of adults and embryos (e.g. Newton 1979). The heavy use of persistent chemicals in such a confined area is bound have far-reaching effects, but there is no evidence either way regarding effects on the owl.

\section{Persecution}

The owl is quite confiding with little fear of predators, like many island species. An early account mentions that one was knocked out of tree by a boy with a stick. Nevertheless, there is little evidence of systematic persecution, although islanders showed a readiness to shoot owls for the collector Bell (Bell 19121913).

The Norfolk Island Birds Protection Ordinance 1913 (with amendments) outlines conditions under which licences were issued for the taking of species, and so forth. However, the owl was not fully protected until a 1970 amendment listed it and several other species under Section 2, which prohibits its capture, shooting or killing for any purpose unless by special licence (Schodde et al. 1983). The owl is also listed in the Norfolk Island Endangered Species Act 1980.

\section{Scientific collecting}

The Sydney collector Bassett-Hull engaged Roy Bell to collect several island species including the owl (Bell 1912-1913). Licensed to take six owls, Bell took 
30 specimens. A further seven were taken during the Whitney South Seas Expedition of 1926. Presumably, early this century the owl population was already stressed by severe loss of habitat, and removal of a relatively large number of birds may have further reduced genetic variability and population stability.

\section{Taxonomic and genetic considerations}

In any conservation programme, taxonomic and genetic considerations are of great importance. The word hybrid often carries bad connotations because it is viewed as the antithesis of racial purity, but hydridization occurs in nature and has a significant role in various evolutionary processes (Cade 1983). There are several biological consequences of hybridization: on the one hand it increases genetic diversity (though not necessarily fitness), but on the other the original genome may be lost if it is swamped by the introduced genome. However, in the case of a form reduced to a single individual hybridization is clearly the only option for conservation.

A complex variety of genetic mechanisms affect small populations. Presumably the original owl population was adapted to rarity and its genetic consequences, and deleterious alleles had been lost (e.g. Soulé 1983, Templeton and Read 1983). A benefit of having a female, rather than a male, as the sole survivor is that she is the heterogametic sex so any sex-linked alleles she may carry will be available to future generations. There is wide variation in the cost of inbreeding (Ralls et al. 1988): small, isolated populations appear able to sustain themselves despite high levels of inbreeding and loss of heterozygosity. One risk inherent in the re-establishment programme is that bringing in outsiders may cause outbreeding depression by the introduction of deleterious genes or disruption of favourable gene combinations (e.g. Price and Waser 1979).

The concept of a minimum viable population size, usually based on genetic considerations, has received much attention (Harris et al. 1987, Simberloff 1988) and its implications are relevant to the Norfolk Island Owl conservation effort. However, it has been argued that, when populations are small, demographic and behavioural concerns (for example, the difficulty of finding mates and chance ecological effects) overshadow genetic concerns (Lande 1988, Craig 1994).

\section{Choice of mate for the Norfolk Island female}

Studies in molecular genetics have shown that morphological taxonomy can give misleading results of two main types: the taxonomic separation of taxa with little evolutionary genetic differentiation and, conversely, the lack of recognition of distinctive forms (Avise 1989). Consequently, conservation efforts can be misdirected as they were in the case of the Dusky Seaside Sparrow Ammodramus maritimus nigrescens (Avise and Nelson 1989). As with the Norfolk Island Owl, an extremely small number of individuals remained and all were of one sex (six males). The survivors were taken into captivity and hybridized with females from another race of $A$. maritimus, chosen on morphological and ecological grounds (e.g. Kale 1987). A later molecular survey (mtDNA) revealed 
Table 4. Measurements of the captured female Norfolk Island Boobook Ninox novaeseelandiae undulata compared with those from skins of undulata in museum collections (AMNH and BMNH), the New Zealand Morepork N. n. novaeseelandiae (from Mees 1964), and the smallest N. boobook, N. b. leucopsis from Tasmania, Australia (from Schodde and Mason 1980).

\begin{tabular}{lll}
\hline Subspecies & Wing $(\mathrm{mm})$ & Tail $(\mathrm{mm})$ \\
\hline Female: & & \\
undulata (live) & 204 & 126 \\
undulata & $202 \pm 4(17,197-209)$ & $130 \pm 5(14,115-137)$ \\
novaeseelandiae & $192 \pm 5(19,183-202)$ & $114(1)$ \\
leucopsis & $213 \pm 2.5(10)$ & $126 \pm 3(10)$ \\
Male: & & \\
undulata & $198 \pm 4(11,189-203)$ & $125 \pm 7(9,124-132)$ \\
novaeseelandiae & $192 \pm 4(10,186-199)$ & $100(1)$ \\
leucopsis & $204 \pm 5(18)$ & $120 \pm 3(18)$ \\
\hline
\end{tabular}

Mean \pm S.D. ( $n$, range) given where appropriate. Adapted from Olsen et al. (1989).

that the Dusky Seaside Sparrow was not a distinct subspecies, and, even if it was worth saving because of its distinctive dark plumage (phenotype), it had been paired with individuals from an inappropriate subspecies (Avise and Nelson 1989). With that salutary lesson in mind, the choice of a mate for the Norfolk Island female was somewhat daunting.

A detailed description of this last survivor is given in Olsen et al. (1989). In appearance she matched an early description of the owl by Mathews (1912) and was more or less identical to a series of about 30 skins held in the American Museum of Natural History, all of which are very uniform in plumage characteristics.

The owl is one of several small, rather similar, hawk-owls that occur in Australasia, the south-west Pacific islands, and the Indonesian archipelagos (Schodde and Mason 1980). The taxonomic status and relationships among these various small hawk-owls is uncertain and in need of genetic clarification. Originally the Australian and New Zealand boobooks were considered one species, $N$. novaeseelandiae (Latham 1801). Later, they were split into two species: $N$. boobook centred in Australia and N. novaeseelandiae in New Zealand. Mathews (1912) placed the Norfolk Island Owl with boobook, but Bassett-Hull (1910) believed that it belonged with novaeseelandiae. Mees (1964) returned the whole group to conspecificity. Others gave the Norfolk Island Owl full specific status (Schodde et al. 1983, Hermes 1985). Today, it is again considered a subspecies of the New Zealand Morepork (Christidis and Boles 1994). To add to the confusion, the owl is occasionally referred to as $N$. n. royana (Mathews 1912) (e.g. Smithers and Disney 1969, Ovington 1978) but undulata takes precedence by more than a hundred years (Mathews 1933, Schodde et al. 1983).

Although distinctive in appearance and size (Table 4), morphologically the Norfolk Island Owl most resembles the New Zealand Morepork rather than the boobooks of the rest of Australia. Compared with many other Australian boobooks, it is small (Table 1), dark-plumaged, with a facial mask that is less obvious and washed grey-white (chocolate brown in boobook). Its cere and feet are yellow, whereas those of other Australian boobooks are grey; its nestlings are sooty grey rather than white. In proportions, the Norfolk Island Owl is a 
Table 5. A comparison of some morphological proportions of the Norfolk Island Boobook compared with owls from the rest of Australia, and New Zealand.

\begin{tabular}{lcc}
\hline Area & Wing formula & Tail length/wing length (\%) \\
\hline Norfolk Island & $1<8 ; 2<6 ; 3<5$ & 65 \\
New Zealand (novaeseelandiae) $^{a}$ & $1<8 ; 2<6 ; 3<5$ & 65 \\
Australia (boobook) $^{a}$ & $1>8 ; 2>6 ; 3>5$ & 58 \\
\hline
\end{tabular}

Wing formula shows the relative lengths of the primaries, numbered from the outermost feather inwards, i.e. the outermost primary is 1 .

${ }^{a}$ Data from Schodde and Mason 1980

typical forest owl: its wings are relatively rounded and its tail long (Table 5). In this respect it is identical to the New Zealand owls and differs from the Australian-centred group which inhabits more open country.

In the absence of molecular studies and in view of the urgency of the situation, it was recommended that if a re-establishment programme was to proceed, then males of the morphologically similar and biogeographically nearest New Zealand Morepork were the obvious choice for introduction. The only other contender would have been the equally distinctive Lord Howe Island Boobook N. n. albaria, which has been extinct since about 1950 .

\section{Outline of major events and re-establishment procedures}

In October 1986 a team of volunteers thoroughly searched the island and located one owl. The owl was trapped, measured and banded and tentatively sexed as female. In July-August 1987 survey confirmed presence of only one owl. Nestbox erection began (three types, all rat-proof). The owl immediately roosted in a deep rather than a long nest-box $(290 \mathrm{~mm}$ long $\times 270 \mathrm{~mm}$ broad $\times 490 \mathrm{~mm}$ deep). Although the islanders were kept well informed of progress, the boxes were situated away from areas often used by the public (to minimize the risk of disturbance) and their location was not publicized.

In September 1987, through the courtesy of the New Zealand wildlife authorities, two male New Zealand Owls (surgically sexed for certainty) were flown to the island and released from nest-boxes into the centre of the female's area of activity and near to the nest-box she used as a roost. For future identification, both males were banded with an individual leg band: stainless steel over which some reflective tape had been glued. On several occasions before the males were released, the female was drawn to their release boxes by the broadcast of taped owl calls. She appeared to pair with one male almost immediately after his release; the second male disappeared soon after release.

In October 1988 the first breeding attempt by the Norfolk Island female occurred: an egg was laid but later broken. The following year, however, breeding was successful, and in 1993 the first successful breeding by hybrid second generation took place.

Nine chicks have been fledged successfully (Table 6), four by the original pair and five by their $F_{1}$ hybrid progeny. Survival appears to be high: at the end of 1994 and start of 1995 all eleven individuals were accounted for, at which time the oldest hybrids were five years old. 
Table 6. Summary of breeding attempts by the owls in nest-boxes on Norfolk Island 1987-1994.

\begin{tabular}{|c|c|c|c|c|c|c|c|c|}
\hline \multirow{2}{*}{ Pair } & \multicolumn{6}{|c|}{ Miamiti $\times$ Tintola } & \multicolumn{2}{|c|}{ Hybrid $F_{1}$ pair } \\
\hline & 1988 & 1989 & 1990 & 1991 & 1992 & 1993 & 1993 & 1994 \\
\hline Laying date (approx.) & Oct & $7 / 10$ & $7 / 10$ & - & - & - & $26 / 9$ & 19 \\
\hline No. eggs & $1^{a}$ & 2 & 2 & $2^{a}$ & $2^{b}$ & $2^{a, c}$ & 3 & 2 \\
\hline No. hatchlings & 0 & 2 & 2 & o & 0 & o & 3 & 2 \\
\hline No. fledglings & 0 & 2 & 2 & o & 0 & o & 3 & 2 \\
\hline Fledging date & - & $14 / 12$ & c. $14 / 12$ & - & - & - & c. $3 / 12$ & $30 / 11$ \\
\hline
\end{tabular}

Miamiti is the last pure bred Norfolk island Boobook and Tintola is an introduced New Zealand Boobook; in 1994, they apparently did not attempt to breed. The hybrid $F_{1}$ pair are their progeny: Double Green (female hatched 1989) and Yellow/red-white (male hatched 1990). 'Egg breakage, cause unknown; "egg breakage, bees appropriated nest box; 'natural nest site.

Details of the initiation and progress of the project can be found in Olsen (1986, 1987, 1989, 1990, 1991, 1994a), Olsen and Moon (1990), Olsen et al. (1989, 1994), Hicks et al. (1990), Hicks (1991) and various reports to the Australian National Parks and Wildlife Service (ANPWS). The original female was left in the wild. Owl presence and activity is monitored regularly, mainly by ANPWS staff and a group of volunteers listening around dusk, by responses to broadcast owl calls (used judiciously), and by careful checking of nest-boxes. If owls appear to have settled in an area lacking nest-boxes, some are provided. The boxes are cleaned out if used by the European Starling, Crimson Rosella or bees. Once a female settles in a box, control of Crimson Rosellas and rats is intensified in the immediate area.

During the breeding season boxes are checked only after the female is seen to depart of her own accord. About one week before fledging, the chicks are weighed, measured and individually banded (with stainless steel Australian Bird and Bat Banding Scheme bands covered with reflective tape); a blood sample is taken for future DNA fingerprinting.

\section{The hybrid offspring}

Two chicks hatched in both 1989 and 1990 and fledged at about five weeks of age (Table 6). Each year the family moved gradually downslope from the nest area, and the fledglings appeared to remain with their parents until the following winter. In 1993 two of the $F_{1}$ progeny, aged three and four years, fledged two chicks, and in 1994 three.

The plumage of the chicks seemed most to resemble that of their New Zealand parent, darker than that of the Norfolk Island Owls. The down was sooty grey and irides vivid yellow, unlike the creamy-white down and brownish irides of the boobooks of Australia. When measured the chicks were about 3.5 to 4.5 weeks old and not fully grown: however, their tarsi and culmen were probably close to full-sized. None of the chicks was as large as the Norfolk Island female (Table 7). Similarly, none was as heavy as the Norfolk Island female but most were heavier than the median weight of 19 New Zealand females: median $170 \mathrm{~g}$, mean $163 \mathrm{~g}$, range $105-212 \mathrm{~g}$ ( 15 males: median $156 \mathrm{~g}$, mean $160 \mathrm{~g}$, range 105$195 \mathrm{~g}$; L. Hedley unpubl. data). The estimated weight of a Norfolk Island male is around $195 \mathrm{~g}$ (based on the female's weight and the average difference in 


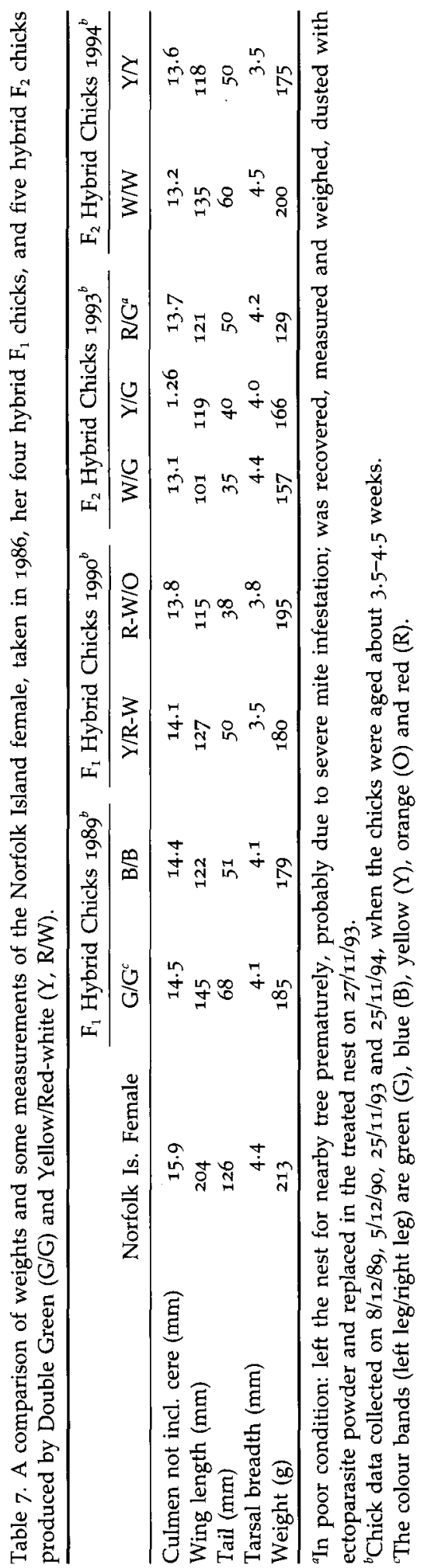


weight between the sexes in New Zealand). Thus it was not possible to determine the sex of the chicks.

In November 1992, a hybrid chick hatched in 1989 (banded Double Blue) was found in a natural tree hole. Inspection revealed four eggs (Table 2), all apparently infertile. As no other owls were seen or heard in the vicinity, after several visits it was concluded that she had no mate. The somewhat dehydrated state of the contents indicated that the eggs had been laid some time before discovery. An estimation of their fresh weight $\left(0.54 \times\right.$ length $\times$ breadth $\left.^{2}\right)$ and a calculation of the percentage loss in weight suggest that they possibly represented two clutches each of two eggs. The eggs are larger than those of the New Zealand owl, but smaller than eggs of other Australian boobooks; they are about the same size as that estimated for the Norfolk Island owl. In 1994, the same owl laid in a nearby nest-box which she shared with another female with two eggs, banded Red-White/Orange; both clutches were infertile. In retrospect, therefore, the four eggs found in 1992 may have been laid by these same two individuals.

\section{Discussion}

Once the decision had been made to attempt a re-establishment programme, the simplest, least invasive form of action was deemed the most acceptable to all involved. The breeding of the owls in the wild, as opposed to the captive alternative, has meant that disturbance of the original female has been minimized and her offspring are adapted to the wild. Overall, monitoring of the breeding pair has not proven difficult. The programme has been low-cost (averaging A \$2,000-3,000 per year) and relatively low-effort.

Forest restoration is under way in NINP, and Philip Island has been cleared of introduced mammalian pests and is regenerating. The latter will eventually provide suitable nest habitat for owls; at present they may visit to hunt. Nevertheless, the owl's habitat, particularly nest sites, has been severely depleted and there is no hope of its restoration within a time-scale that is likely to benefit the recovery of the owl population. However, boobooks in general are versatile in their habitat requirements and provided that nest-boxes are supplied and the few natural sites maintained there seems no reason why the island cannot once again support a healthy wild population. The owls have shown potential for recovery as demonstrated by the early, modest success of the recovery programme.

The Recovery Plan for the owl (Olsen 1994b) complements plans for other species and other conservation initiatives on the island. Its main objectives are: (1) to re-establish a self-sustaining owl population, with need for only minimal management, ideally within 20 years; (2) to ensure that the population makes full use of any suitable habitat in the island group; and (3) to reduce or eliminate major threats. This last is to be achieved mainly via the application of Recovery Plans for other species on the island, by other management initiatives, particularly in NINP, and through fostering cooperation with the public.

Because the owls breed only once a year, with a two-egg clutch, the recovery has been slow. Removal of a clutch to an incubator or to surrogate parents, allowing the owls to relay, was previously considered to carry unacceptable 
risks, but is now an option for the future. The apparent shortage of males raises another option: the introduction of more males from New Zealand.

Until a viable population has been established no decision will be made regarding management to select for the original phenotype or to recontruct the Norfolk Island allelic character by back-crossing. Although the re-establishment effort aims to save at least a portion of the genetic character of the Norfolk Island Boobook, which presumably had superior adaptation for the local environment, the island will never be returned to its original state, so it may be best to let nature select phenotypes best suited to present-day conditions.

Another difficulty with the hands-off, wild-based programme has been to monitor the owls precisely, hence to protect them from various adversities, and always to know their whereabouts and activities, particularly those of the hybrid offspring once they reach independence. Future work will probably include radio-tracking of the juveniles.

There is potential for conflict between the owl recovery programme and the rat control programme, both conducted by the ANCA. Rats are significant predators of eggs and chicks of the island's smaller birds and destroy much young vegetation, hampering revegetation efforts. Over the past decade, techniques for the management of wild birds and broadscale control of introduced pests have been developed and successfully applied by ANCA staff. However, control by baiting carries with it the risk of secondary poisoning of the owls, which occasionally eat rats. Various control measures have been tried, most recently Quintox. Early results from the recent rat poisoning campaign, which apparently controlled the black rat more successfully than the Polynesian rat, indicated that a direct result may have been improved reproductive success of Green Parrots. If the Polynesian rats are less harmful to nesting birds, and are prey for the owl, then their control may be unnecessary.

Boobook owls breed fairly readily in captivity and are undemanding in their requirements. Captive breeding may be considered in the future, the main objective being to produce owls to augment the wild population, although the many concerns over captive-based recovery efforts (Craig 1994, Magin et al. 1994) make it a low-ranking option. Nevertheless, a display of captive owls would generate interest in and increase understanding of the owls and other conservation issues, and at some stage it may be useful to establish a small captive colony off-island as an insurance against unforeseen catastrophe.

One of the important benefits of the recovery programme is that its early success must give hope to other conservation projects for species with limited numbers of individuals. The extraordinary plight of the original owl, and her and her chicks' physical appeal, has generated wide media coverage and captured the attention of many in positions of authority and the public at large. The project has strengthened relations between the Norfolk Islanders and ANPWS, benefiting other conservation efforts on the island. Not least, it has given a great boost to island conservation in Australia, previously much neglected. Although King (1985) estimated that $93 \%$ of extinct land and freshwater birds are oceanic island species, until quite recently Australia's conservation concerns were focused elsewhere, particularly on the exceptionally high rate of extinction of arid zone mammals (see Kennedy 1990, Recher and Lim 1990). 


\section{Acknowledgements}

Many have generously assisted with the project and several continue to contribute. Robert Bartos, John Kershaw, Bernie Mace and Nick Mooney were voluntary members of the survey team which located and trapped the owl and established that she was the last. Derek Greenwood carries out the bulk of the routine owl monitoring and management, assisted mainly by Ron Ward, also Margaret Christian, John Anderson, Owen and Arthur Evans and other islanders. Mary LeCroy (American Museum of Natural History) sent colour slides and measurements of specimens in the collection, and Graham Cowles (British Museum) sent measurements. The programme would not have proceeded without the efforts and enthusiasm of John Hicks, ANPWS Conservator on the island until 1990. Many others have given advice and support, including: Edric Slater, Peter Fullagar, Paul Stevenson, Neil Hermes, Gordon Anderson, Graeme Chapman and Ed McNabb.

\section{References}

Anon. (1989) Philip Island revised plan of management. Canberra: Australian National Parks and Wildlife Service.

Anon. (1994) Cats copping a bum rap, says university researcher. Tallagandra Times, Wednesday, June 15.

Atkinson, I. A. E. (1978) Evidence of the effects of rodents on the vertebrate wildlife of New Zealand islands. Pp.7-30 in P. R. Dingwall, I. A. E. Atkinson and C. Hay, eds. The ecology and control of rodents in New Zealand nature reserves. Department of Lands and Survey (Information Series 4).

Atkinson, I. A. E. (1985) The spread of commensal species of Rattus to oceanic islands and their effects on island avifaunas. Pp.35-81 in P.J. Moors, ed. Conservation of island birds. Cambridge, U.K.: International Council for Bird Preservation (Tech. Publ. 3).

Avise, J. C. (1989) A role for molecular genetics in the recognition and conservation of endangered species. Trends Ecol. Evol. 4: 279-281.

Avise, J. C. and Nelson, W. S. (1989) Molecular genetic relationships 'of the extinct Dusky Seaside Sparrow. Science 243: 646-648.

Bassett-Hull, A. F. (1910) The birds of Lord Howe and Norfolk Islands. Proc. Linn. Soc. New South Wales 34: 636-693.

Bell, R. (1912-1913) Diary on Norfolk Island. Australian Museum, Sydney (unpublished manuscript).

Best, E. (1966) The journal of Ensign Best, 1837-1843. Wellington: Government Printer.

Cade, T. J. (1983) Hybridization and gene exchange among birds in relation to conservation. Pp. 288-309 in C. M. Schonewald-Cox, S. M. Chambers, B. MacBryde and W. L. Thomas, eds. Genetics and conservation. Menlo Park, California: Benjamin/Cummings.

Caughley, G. (1994) Directions in conservation biology. J. Anim. Ecol. 63: 215-244.

Christidis, L. and Boles, W. (1994) The taxonomy and species of birds of Australia and its territories. Roy. Australas. Orn. Union Monogr. 2.

Clarke, R. J., Smith, D. G. and Kelso, H. (1978) Working bibliography of owls of the world. Washington, D.C.: Raptor Information Centre, National Wildlife Federation.

Craig, J. L. (1994) Meta-populations: is management as flexible as nature? Pp.50-66 in P. J. S. Olney, G. M. Mace and A. T. C. Feistner, eds. Creative conservation. London: Chapman and Hall. 
De Ravin, J. A. (1975) The birds of Norfolk Island. Aust. Bird Watcher 6: 4-10.

Diamond, J. M. and Veitch, C. R. (1981) Extinctions and introductions in New Zealand avifauna: cause and effect? Science 211: 499-501.

Dietz, J. M., Dietz, L. A. and Nagagata, E. Y. (1994) The effective use of flagship species for conservation of biodiversity: the example of lion tamarins in Brazil. Pp.32-49 in P. J. S. Olney, G. M. Mace and A. T. C. Feistner, eds. Creative conservation. London: Chapman and Hall.

Garnett, S., ed. (1992) Threatened and extinct birds of Australia. RAOU Report 82.

Gilmore, P. and Helman, C. (1989) The vegetation of Norfolk Island National Park. Australian National Parks and Wildlife Service, unpublished report.

Harris, R. B., Maguire, L. A. and Schafer, M. L. (1987) Sample sizes for minimum viable population estimates. Conserv. Biol. 1: 72-76.

Hermes, N. (1985) Birds of Norfolk Island. Norfolk Island: Wonderland Publications.

Hermes, N. (1986) A revised annotated checklist of vascular plants and vertebrate animals of Norfolk Island. Norfolk Island: Flora and Fauna Society; and Canberra: Australian National Parks and Wildlife Service.

Hicks, J. (1991) The last owl. Panorama 101: 46-50.

Hicks, J. and Preece, M. (1991) Recovery plan for the Norfolk Island Green Parrot Cyanoramphus novaezelandiae cookii. Canberra: Australian National Parks and Wildlife Service.

Hicks, J., Olsen, P. and Greenwood, D. (1990) Saving the last survivor. Birds International 2(10): 66-73.

Hoare, M. (1974) The discovery of Norfolk Island. Canberra: Australian Goverment Publ. Service.

Kale, H. W. (1987) The Dusky Seaside Sparrow: have we learned anything? Florida Naturalist 60: 2-3.

Kennedy, M, ed. (1990) Australia's endangered species. Brookvale: Simon and Schuster.

Kepler, C. B. (1967) Polynesian rat predation on nesting Laysan Albatrosses and other Pacific seabirds. Auk 84: 426-430.

King, P. G. (1788-1790) Unpublished journal. Sydney: Mitchell Library.

King, W. B. (1978-1979) Red Data Book, 2: Aves. Second edition. Morges, Switzerland: International Union for Conservation of Nature and Natural Resources.

King, W. B. (1985) Island birds: will the future repeat the past? Pp.3-15 in P. J. Moors, ed. Conservation of island birds. Cambridge: International Council for Bird Preservation (Techn. Publ. 3).

Lande, R. (1988) Genetics and demography in biological conservation. Science 241: 14551460 .

Lane-Poole, C. E. (1926) Report on the forests of Norfolk Island. Melbourne: Government Printer of Victoria.

Latham, J. (1801) Supplementum Indicis Ornithologici. London: Leigh and Sotheby.

Magin, C. D., Johnson, T. H., Groombridge, B., Jenkins, M. and Smith, H. (1994) Species extinctions, endangerment and captive breeding. Pp.3-31 in P. J. S. Olney, G. M. Mace and A. T. C. Feistner, eds. Creative conservation. London: Chapman and Hall.

Mathews, G. M. (1912) The geographic relationships of the birds of Lord Howe, Norfolk and Kermadec Islands. Austral. Avian Rec. 1: 121-122.

Mathews, G. M. (1933) On the name of the Boobook Owl and on the genera Emblema and Paranectris. Ibis (13)3: 353.

Mees, G. F. (1964) A revision of the Australian owls (Strigidae and Tytonidae). Zool. Verhandel. 65.

Moore, J. L. (1981) Norfolk Island notes 1971 to 1980. Notornis 28: 50-56.

Moors, P. J., ed. (1985) Conservation of island birds. Cambridge, U.K.: International Council for Bird Preservation (Techn. Publ. 3).

Newton, I. (1979) Population ecology of raptors. Calton: Poyser. 
Olsen, P. (1986) Status and conservation of the Norfolk Island Boobook Ninox noveaseelandiae undulata. Canberra: Australian National Parks and Wildlife Service, unpublished report.

Olsen, P. (1987) Conservation of the Norfolk Island Boobook Owl. Canberra: Australian National Parks and Wildlife Service, unpublished report.

Olsen, P. (1989) The very last of the Norfolk Island Boobook. Geo 11(2): 70-77.

Olsen, P. (1990) Norfolk Island Owl-wild breeding program. Report on visit to island, December 1989. Canberra: Australian National Parks and Wildlife Service, unpublished report.

Olsen, P. (1991) Norfolk Island Owl-wild breeding program. Report on visit to island, December 1990. Canberra: Australian National Parks and Wildlife Service, unpublished report.

Olsen, P. (1994a) Norfolk Island Owl Recovery Program: report on visit to Norfolk Island, November 1993. Canberra: Australian National Parks and Wildlife Service, unpublished report.

Olsen, P. (I994b) Recovery plan for the Norfolk Island Boobook Owl Ninox novaeseelandiae undulata. Preliminary Draft. Canberra: Australian Nature Conservation Agency.

Olsen, P., Hicks, J., Mooney, N. and Greenwood, D. (1994) Progress of the Norfolk Island Owl Ninox novaeseelandiae undulata re-establishment programme. Pp.575-578 in B.-U. Meyburg and R. D. Chancellor, eds. Raptor conservation today. London: World Working Group on Birds of Prey.

Olsen, P. and Moon, G. (1990) Of boobooks and moreporks. Birds International 2(4): 26-33.

Olsen, P. D., Mooney, N. J. and Olsen, J. (1989) Status and conservation of the Norfolk Island Boobook Ninox novaeseelandiae undulata. Pp.415-422 in B.-U. Meyburg and R. D. Chancellor, eds. Raptors in the modern world. London: World Working Group on Birds of Prey.

Ovington, D. (1978) Australian endangered species. Australia: Cassel.

Potter, C. ed. (1991), The impact of cats on native wildlife. Canberra: Australian National Parks and Wildlife Service.

Price, M. V. and Waser, N. M. (1979) Pollen dispersal and optimal outcrossing in Delphinium nelsoni. Nature 277: 294-298.

Ralls, K., Ballou, J. D. and Templeton, A. (1988) Estimates of lethal equivalents and the costs of inbreeding in mammals. Conserv. Biol. 2: 185-193.

Recher, H. F. and Lim, L. (1990) A review of current ideas of the extinction, conservation and management of Australia's terrestrial vertebrate fauna. Proc. Ecol. Soc. Austral. 16: 287-301.

Rooke, I. (1986) Survey of the White-breasted White-eye and the Norfolk Island Boobook Owl on Norfolk Island, October-November 1985. Roy. Australas. Orn. Union Report 22.

Schodde, R., Fullagar, P. and Hermes, N. (1983) A review of Norfolk Island birds: past and present. Canberra: Australian National Parks and Wildlife Service, Commonwealth of Australia.

Schodde, R. and Mason, I. J. (1980) Nocturnal birds of Australia. Melbourne: Lansdowne.

Simberloff, D. (1988) The contribution of population and community ecology to conservation science. Ann. Rev. Ecol. Syst. 19: 473-511.

Smithers, C. N. and Disney, H. J. de S. (1969) The distribution of terrestrial and freshwater birds on Norfolk Island. Austral. Zool. 15: 127-140.

Soulé, M. E. (1983) What do we really know about extinction? Pp.111-124 in C. M. Schonewald-Cox, S. M. Chambers, B. MacBryde and W. L. Thomas, eds. Genetics and conservation. Menlo Park, California: Benjamin/Cummings.

Templeton, A. R. and Read, B. (1983) The elimination of inbreeding depression in a captive herd of Speke's Gazelle. Pp.241-261 in C. M. Schonewald-Cox, 
S. M. Chambers, B. MacBryde and W. L. Thomas, eds. Genetics and conservation. Menlo Park, California: Benjamin/Cummings.

Turner, J. S., Smithers, C. N. and Hoogland, R. D. (1968) The conservation of Norfolk Island. Austral. Cons. Found. Spec. Publ. no. 1.

Veitch, C. R. (1985) Methods of eradicating feral cats from offshore islands in New Zealand. Pp.125-141 in P. J. Moors, ed. Conservation of island birds. Cambridge, U.K.: International Council for Bird Preservation (Tech. Publ. 3).

Wakelin, H. (1968) Some notes on the birds of Norfolk Island. Notornis 15: 175-176.

PENNY D. OLSEN

Behavioural Ecology Group, Division of Botany and Zoology, Australian National University, Canberra, ACT 0200, Australia. 